

UDC 637.3:664(06)

\title{
Technological characteristics of processed and prophylactic processed cheese with a new phytospection "Ukrainska kukhnia"
}

\author{
Yu. R. Hachak, V. O. Nagovska, B. V. Gutyj, O. R. Mykhaylytska, V. M. Koberniuk \\ Stepan Gzhytskyi National University of Veterinary Medicine and Biotechnologies Lviv, Ukraine
}

Article info

Received 11.02.2020

Received in revised form 12.03 .2020

Accepted 13.03.2020

Stepan Gzhytskyi National University of Veterinary Medicine and Biotechnologies Lviv, Pekarska str., 50, Lviv, Ukraine. Tel.: +38-097-331-99-23 E-mail: hachakyuriy@gmail.com
Hachak, Yu. R., Nagovska, V. O., Gutyj, B. V., Mykhaylytska, O. R., \& Koberniuk, V. M. (2020). Technological characteristics of processed and prophylactic processed cheese with a new phytospection "Ukrainska kukhnia". Scientific Messenger of Lviv National University of Veterinary Medicine and Biotechnologies. Series: Food Technologies, 22(93), 66-71. doi: $10.32718 /$ nvlvet-f9312

An important task for food processing enterprises is the search, development and implementation of cost-effective, technically advanced and environmentally friendly technologies for the food industry. Recently, a promising direction in the production of food products - treatment and prevention products containing a variety of supplements, including and vegetable. Medicinal properties of food herbs are due to the presence of biologically active substances, including various vitamins, micro-, macronutrients and various enzymes. The purpose of the experiments was to study the optimal ratios of prescription components for the production of processed cheese "Ukrainian" with the use of vegetable spices, study the possibility and methods of using them in the production process of a new type of processed cheese in the enterprise, development of optimal doses of "Ukrainska kuchnia". According to the research plan, the experiments were conducted in the central laboratory and production shops of Ivano-Frankivsk Dairy Plant, Department of Milk and Dairy Products Technology, Stepan Gzhytskyi National University of Veterinary Medicine and Biotechnologies Lviv. National species "Ukrainska kuchnia" was used for research. As evidenced by the results of the tasting evaluation of these prototypes, the best organoleptic evaluation was received by the recipe № 2 the composition of which provides (per $1000 \mathrm{~kg}$ of finished product): $373 \mathrm{~kg}$ of rennet Dutch cheese; 63.2 low-fat cheese; 30.6 cow's milk powder; $39.7 \mathrm{~kg}$ of peasant oil, salt solution of the ruler $102 \mathrm{~kg} ; 107.2 \mathrm{~kg}$ of drinking water and $14.0 \mathrm{~kg}$ of spices "Ukrainska kuchnia" per $1000 \mathrm{~kg}$ of finished product. Additions to the recipe of the phytospection "Ukrainska kuchnia" led to a certain change in the organoleptics of the prototypes of the proposed salted processed cheese, of course with the acquisition of certain characteristics of the filler - spices "Ukrainska kuchnia". All experimental samples of cheese were characterized by the same values of mass fraction of moisture $-51.7 \% \mathrm{vs} .52 \%$ in the prototype, salt content $2.8 \%$ vs. $3.0 \%$, and the pH of experimental samples of processed cheese "Ukrainian" was respectively 5.6, which corresponds regulatory requirements. From the results of the tasting evaluation of the samples, all of them met the regulatory requirements and received quite high characteristics (28 and 29 points, respectively). In parallel, a microbiological evaluation of processed cheeses was performed. In evaluating the obtained data, both traditional products and prototypes had regulatory safety indicators. At the same time, no harmful and dangerous microflora was detected. Summarizing the above experimental data, it can be noted that the use as a recipe component for the production of processed cheese spice "Ukrainska kuchnia" based on processed cheese "Hostryi z pertsem" is appropriate, and the resulting product is biologically valuable, has proper product characteristics, safety indicators and expands the range of domestic dairy products for treatment and prevention.

Key words: processed cheese, phytospection "Ukrainska kuchnia", technology, food products.

\section{Технологічні характеристики плавленого сиру лікувально- профілактичного спрямування із новою фітоспецією "Українська кухня"}

Ю. Р. Гачак, В. О. Наговська, Б. В. Гутий, О. Р. Михайлицька, В. М. Кобернюк 
Львівський національний університет ветеринарної медицини та біотехнологій імені С. 3. Гжицького, м. Львів, Україна

Важливим завданням для харчопереробних підприємства є пошук, розроблення та впровадження економічно ефективних, технічно удосконалених та екологічно чистих технологій для харчової промисловості. Останнім часом широко розвивається перспективний напрям при виробництві харчових продуктів - продукти лікувально-профілактичного напрямку, щзо містять різноманітні біодобавки, в т.ч. і рослинні. Лікувальні властивості харчових лікарських рослин обумовлені наявністю в них біологічно активних речовин, включаючи різноманітні вітаміни, мікро-, макроелементи і різного роду ферменти. Метою експериментів було вивчення оптимальних співвідношень рецептурних компонентів для виробництва плавленого сиру “Украйнський” із використанням рослинних спецій, дослідження можливості та методів використання їх в технологічному процесі виробництва нового виду плавленого сиру в умовах підприємства, розробки оптимальних доз приправи “Украӥнська кухня”. Згідно плану наукових досліджень експерименти проводились в умовах центральної лабораторї та виробничих цехів Івано-Франківського молокозаводу, кафедри технології молока і молочних продуктів Львівського начіонального університету ветеринарної медицини та біотехнологій імені С. 3 . Гжицького. Для досліджень використовували вітчизняну приправу “Украйнська кухня”. Як засвідчили результати дегустаційної оцінки даних дослідних зразків, найкращу органолептичну оцінку отримала рецептура № 2 склад якої передбачає (розрахунок на 1000 кг готового продукту): 373 кг сиру сичужного голландського; 63,2 сиру нежирного; 30,6 молока коров'ячого сухого; 39,7 кг масла селянського, розчину солі правителя 102 кг; 107,2 кг води питної та 14,0 кг спецї “Украӥнська кухня” із розрахунку на 1000 кг готового продукту. Додавання до рецептури фітоспеції “Українська кухня” привели до певної зміни органолептики дослідних зразків пропонованого соленого плавленого сиру, зрозуміло із надбанням певних характерних ознак наповнювача - спеції “Украйнська кухня”. Всі дослідні зразки сиру характеризувались однаковими величинами масової частки вологи - 51,7 \% проти 52 \% у прототипі, вміст солі 2,8 \% проти 3,0\%, а рН дослідних зразків плавленого сиру “Украӥнський” відповідно складав 5,6, щзо відповідає нормативним вимогам. Із результатів дегустаційної оцінки зразків, всі вони відповідали нормативним вимогам і отримали досить високі характеристики (відповідно 28 та 29 балів). Паралельно була проведена мікробіологічна оцінка плавлених сирів При оцінці отриманих даних як традииійна продукиія, так і дослідні зразки мали нормативні показники безпеки. В той же час шкідливої та небезпечної мікрофлори виявлено не було. Підсумовуючи вище наведені експериментальні дані, можна відзначити, щчо використання в якості рецептурного складника для виробництва плавленого сиру спеції “Українська кухня” на основі плавленого сиру “Гострий із перием” є доцільним, а отримана продукція є біологічно цінною, має належні товарознавчі характеристики, показники безпеки і розширює асортимент вітчизняної молочної продукції лікувально-профілактичного спрямування.

Ключові слова: плавлений сир, фітоспечія “Украӥнська кухня”, технологія, харчові продукти.

\section{Вступ}

Протягом багатьох тисячоліть, люди пересвідчувались в тому, що рослини лікують численні захворювання органів дихання, органів травлення, серцевосудинної системи, сечовипускання, печінки, центральної нервової системи, а також шкірні недуги. Нас оточують тисячі видів рослин, які $є$ не лише джерелами харчування людини, але й джерелом чудових лікарських засобів.

Лікувальні властивості харчових лікарських рослин обумовлені наявністю в них біологічно активних речовин, включаючи різноманітні вітаміни, мікро-, макроелементи і різного роду ферменти. Ці речовини знаходяться в рослинах у порівняно незначних кількостях, однак, як правило, здійснюють на наш організм сильний вплив. Актуальність використання лікувальних рослин, в число яких входять і пряні, значно зросла в останні десятиліття. І це пояснюється в першу чергу тим, що різко зросла кількість ускладнень від застосування аптечної хімії (навіть із смертельними випадками).

Останнім часом широко розвивається перспективний напрям при виробництві харчових продуктів продукти лікувально-профілактичного напрямку, що містять різноманітні біодобавки, в т. ч. і рослинні (Hrek \& Skorchenko, 2012; Pavliuk et al., 2013; Steshenko et al., 2015; Gutyj et al., 2017; Lanycja, 2017; Gachak et al., 2018; Boichak et al., 2018). Особливої уваги в цьому плані заслуговують натуральні рослинні біодобавки. Останні, за рахунок своїх природних властивостей, надають даним молочним продуктам лікувально-профілактичних властивостей.

При одержанні комбінованих масел, м'яких, сичужних сирів почали використовувати різновиди плодо- во-ягідної сировини, диких та лікарських рослин, морські продукти, продукти бджільництва та збагачені лікувально-профілактичного призначення (Hoiko \& Pryshepa, 2014; Ilinska et al., 2017; Koberniuk et al., 2018; Hachak et al., 2018).

Особливої уваги в цьому плані заслуговують натуральні рослинні біодобавки у формі спецій. Приправи i спеції, такі як шафран кріп, перець, часник, пастернак, які надають численним стравам та блюдам яскравого смаку та аромату, стали невід'ємною частиною національних культурних традицій нашого народу. I зацікавленість у використанні поживних властивостей даних добавок щороку зростає як зі сторони науковців, так і виробничників.

Так, Гачак Ю.Р., Печар Н. (2009) використали в якості лікувально-профілактичної добавки при виробництві плавлених сирів екстракт ехінацеї.

Не $\epsilon$ винятком в цьому плані і використання в якості молочної рослинних біодобавок окремих спецій та приправ. Так, Домнюк О., Гачак Ю. (2008) рекомендують технологію сиру “Домашній” із кмином, петрушкою та кропом, а також інших спецій і добавок (Hachak, 2011).

Гачак Ю., Садикова Є. (2011) вивчили та довели доцільність використання 2-х вітчизняних спеційпряностей "Хмелі-сунелі" та "Італійські трави” в технологіï аналогічного продукту (Hachak \& Sadykova, 2011).

Виходячи з цього, використання рослинних спецій та приправ у різних формах в якості додаткових рецептурних складників в технології, наприклад плавлених сирів є оправданим.

Метою проведення наших досліджень було застосування нової вітчизняної приправи “Українська кухня” в технології плавленого сиру, що видається нам 
перспективним не лише з точки зору створення нових вітчизняних лікувально-профілактичних продуктів, але й розширення асортименту підприємств України, що виробляють аналогічну продукцію.

\section{Матеріал і методи досліджень}

Згідно плану наукових досліджень експерименти проводились в умовах центральної лабораторії та виробничих цехів Івано-Франківського молокозаводу, кафедри технології молока i молочних продуктів Львівського національного університету ветеринарної медицини та біотехнологій імені С. 3. Гжицького. Для досліджень використовували вітчизняну приправу “Українська кухня". Біологічна цінність даної приправи обумовлена іiі складовими. Універсальна приправа "Українська кухня" поєднує традиційні прянощі та спеції: кріп, перець, часник, цибулю, петрушку та моркву. Крім цього іiі використовують як смакову та ароматичну приправу (Hachak, 2011; Hachak \& Mykhailytska, 2014).

Кріп - діє заспокоююче на нервову систему, знімає безсоння, коліки у шлунку. Корисним він $є$ для хворих гіпертонією та хронічною коронарною недостатністю. Це чудова складова частина раціону для грудних дітей від запорів. Він також добре діє на органи виділення.

Перець - стимулює секреторну діяльність травного каналу, володіє антисептичною дією, особливо корисний при простудних хворобах, кашлі, ревматизмі, невралгії.

Часник - застосовують як найкращий засіб проти склерозу і малокрів ї, проти слабості, гіпертонії, стенокардії, бронхіальній астмі.

Петрушка - володіє чудодійною оздоровчою силою, містить значний набір вітамінів, мінеральних речовин. Так, у петрушці міститься значно більше вітаміну С ніж у лимоні, провітаміну А більше ніж в моркві. У ній також є залізо, кальцій, магній, фосфор. Петрушка містить багато ефірних масел (особливо у насінні), вона збуджує апетит, покращує травлення. Насіння приймають і при набряках серцевого походження.

Морква - лікувальна рослина, яку широко використовують в гастрономії як найпопулярнішу приправу, вона може, бути також і основним продуктом. Морква - дуже корисний овоч для організму. Морква містить вітаміни групи В, РP, C, Е, К. Морква містить 1,3\% білків, 7 \% вуглеводів. Немало в моркві мінеральних речовин, необхідних для організму людини: калію, заліза, фосфору, магнію, кобальту, міді, йоду, цинку, хрому, нікелю, фтору і ін. У моркві містяться ефірні олії, які обумовлюють іiі своєрідний запах. Морква містить бета-каротин, який покращує роботу легенів. Бета-каротин є попередником вітаміну А. Потрапляючи, в організм людини каротин перетворюється на вітамін А. Цей вітамін необхідний для нормального зору, він підтримує у хорошому стані шкіру і слизові оболонки. Морква, страви з моркви і особливо морк- вяний сік використовуються в лікувальному харчуванні при гіпо- і авітамінозі А, захворюваннях печінки, серцево-судинної системи, нирок, шлунку, недокрів “і, поліартриті, порушеннях мінерального обміну. Володіє цей овоч і протимікробними властивостями. У моркві містяться фітонциди.

В якості молочної основи нами використано сир плавлений “Гострий із перцем”, а його рецептуру як базову із наступними компонентами, поряд 3 сичужним сиром - голландським, складниками якого $є$ сухе знежирене молоко, масло селянське, сіль-плавитель (триполіфосфату натрію) та вода питна. Кількість самого гострого перцю в процесі наукового пошуку було практично кількісно замінено на пропоновану приправу “Українська кухня”.

Як засвідчили патентні дослідження подібної продукції на даний час не запатентовано, в той час як виробнича потреба у таких розробках $є$ значна.

Згідно плану наукового пошуку було заплановано розробку рецептур нового плавленого сиру із пропонованою приправою "Українська кухня" на базі сиру "Гострий із перцем". Компоненти суміші для плавлення попередньо готувались згідно вимог технологічних інструкцій при виробництві плавлених сирів. Плавлення суміші здійснювали при температурі 80 $82{ }^{\circ} \mathrm{C}$. Вибір та пошук доз складників проводився: при збереженні максимально наближених нормативних характеристик плавленого сиру; забезпечення смакових характеристик плавленого сиру із додаванням пропонованої біодобавки.

Дослідження проб готової продукції здійснювали відповідно до ГОСТ 26809-86 “Молоко і молочні продукти. Правила приймання. Методи відбору і підготовка проб аналізу” та ДСТУ ISO 707-2002 “Молоко і молочні продукти. Настанови з відбирання проб”; ДСТУ ISO 5538:2004 "Молоко і молочні продукти. Відбирання проб. Контроль за якісними показниками” (Shidlovskaja, 2000; Kozak et al., 2012; Yatsenko et al., 2016).

В подальшому, встановлені співвідношення були перераховані згідно вимог промислової рецептури (на 1000 кг готового продукту без врахування виробничих втрат).

\section{Результати та їх обговорення}

Розробка рецептур плавленого сиру із фітоспещі$є ю$ “Украӥнська кухня". Нашими експериментами ми намагалися максимально зберегти нормативні органолептичні характеристики та технологічні параметри молочної основи (плавленого сиру) та спецій, знайти їх оптимальне співвідношення. Оцінка 2-х серій проведених досліджень та робота дегустаційної комісії в умовах підприємства, університету дозволили вибрати найбільш вдале співвідношення зразків сиру плавленого "Пряний” із різними дозами рослинної спеції, а саме - "Українська кухня".

Як основу нами вибрано рецептуру, на основі якої ми і проводили власні дослідження (табл. 1). 


\section{Таблиця 1}

Рекомендовані рецептури плавленого сиру “Гострий із перцем” та із спецією "Українська кухня"

\begin{tabular}{|c|c|c|}
\hline \multirow{2}{*}{$\begin{array}{l}\text { Сировина при виготовленні плавленого сиру } \\
\text { "Пряний” }\end{array}$} & \multicolumn{2}{|c|}{ Сир плавлений із спеціями } \\
\hline & "Гострий із перцем" & "Український" \\
\hline Сир “Голландський” (мчж 45 \%) & 663,0 & 663,0 \\
\hline Сир нежирний ( мч СР 40 \%) & 64,2 & 63,2 \\
\hline Молоко коров'яче сухе знежирене (мч СР 96 \%) & 30,6 & 30,6 \\
\hline Суміш триполіфосфат натрію (мч СР 20 \%) & 102,0 & 102,0 \\
\hline Масло “Селянське” (мч СР 75 \%, мчж 72,5 \%) & 39,7 & 39,7 \\
\hline Вода питна & 107,5 & 107,5 \\
\hline Перець: червоний, духмяний, гіркий по 1,0 & 3,0 & - \\
\hline Сіль кухонна & 10,0 & - \\
\hline Спеція “Українська кухня” & - & 14,0 \\
\hline Всього & 1020 & 1020 \\
\hline Вихід & 1000 & 1000 \\
\hline
\end{tabular}

Як засвідчили результати дегустаційної оцінки даних дослідних зразків, найкращу органолептичну оцінку отримала рецептура № 2 склад якої передбачає (розрахунок на 1000 кг готового продукту): 373 кг сиру сичужного голландського; 63,2 сиру нежирного; 30,6 молока коров'ячого сухого; 39,7 кг масла селянського, розчину солі правителя 102 кг; 107,2 кг води питної та 14,0 кг спеції "Українська кухня" із розрахунку на 1000 кг готового продукту.

Певні зміни в рецептурах нормативного складу привели і до зміни органолептики дослідних зразків плавлених сирів із спеціями.

Органолептичні та технологічні властивості плавленого сиру “Український”. Органолептичні та технологічні властивості дослідження плавленого сиру входять до комплексу досліджень, передбачених нормативними документами щодо даного виду продукції і входять до схеми технологічного контролю плавлених сирів .
Оцінка та визначення органолептичних якостей сиру є основним фактором для встановлення рівня цін для кожного продукту, дозволяючи виявляти, а потім і ліквідувати можливі недоліки при їх виготовлені; $є$ важливим фактором у забезпеченні для сиру постійного та надійного споживача.

При комплексній оцінці нових чи модифікованих зразків сирів серед органолептичних характеристик особливе значення в оцінці якості продукції мають запах, смак, консистенція, колір виробів. Важливе значення має також товарний вигляд продукції - ступінь наповнення упаковки, щільність і правильність фасування, іiї зовнішній вигляд.

Додавання до рецептури кріопорошку "Українська кухня" привело до певної зміни органолептики дослідних зразків пропонованого соленого плавленого сиру, зрозуміло із надбанням певних характерних ознак наповнювача - спеції "Українська кухня" (табл. 2).

Таблиця 2

Порівняльна характеристика органолептичних показників плавленого сиру “Гострий із перцем” та із спецією "Українська кухня"

\begin{tabular}{lll}
\hline \multicolumn{1}{c}{ Назва показника } & $\begin{array}{c}\text { Традиційний плавлений “Гострий } \\
\text { із перцем” }\end{array}$ & Сир плавлений із спецією “Українська кухня” \\
\hline Смак і запах & $\begin{array}{l}\text { Гострий, із вираженим присмаком } \\
\text { внесених спецій }\end{array}$ & Ситний смак (присмак масла та спеції), чітко виражений \\
Консистенція & В міру щільна, злегка пружна & В міру щільна, злегка пружна \\
Колір тіста & Обумовлений вкрапленнями час- & Яскраво-жовтого кольору, наявні численні включення \\
Вид на розрізі & тинок спецій & зеленого, червоного кольору різного розміру \\
Зовнішній вигляд & Щільна маса без вічок & Щільна маса без вічок \\
& Поверхня чиста, не підсохла, не & Поверхня чиста, не підсохла, блискуча \\
\hline
\end{tabular}

Як ми можемо побачити з характеристик дослідні зразки сиру зберігають ніжну, еластичну консистенцію, зовні мають блиск; мають характерний оригінальний смак і запах (ситний смак, свіжий). Дослідні зразки зовні мали кірочку, на розрізі - суцільну масу. Колір дослідних зразків був світло-жовтий, наявні зеленувато-червоні вкраплення різного розміру та форми. Це очевидно, пов'язано із впливом у рецептурній масі самої спеції - добавки.

Фізико-хімічні характеристики плавленого сиру із додаванням спеції “Українська кухня" наведені у таблиці 3. 
Таблиця 3

Фізико-хімічні показники плавленого сиру “Гострий із перцем” та із спецією "Українська кухня"

\begin{tabular}{|c|c|c|c|c|c|}
\hline \multirow[b]{2}{*}{ Назва сиру } & \multicolumn{3}{|c|}{ Вміст, \% } & \multirow[b]{2}{*}{ pH сиру } & \multirow{2}{*}{$\begin{array}{c}\text { Форма і маса } \\
\text { (г) }\end{array}$} \\
\hline & $\begin{array}{c}\text { жиру в сухій } \\
\text { речовині }\end{array}$ & $\begin{array}{l}\text { вологи, не } \\
\text { менше }\end{array}$ & $\begin{array}{l}\text { солі, не } \\
\text { менше }\end{array}$ & & \\
\hline $\begin{array}{l}\text { Нормативні вимоги, щодо плавленого } \\
\text { сиру “Гострий із перцем” }\end{array}$ & 40 & 52 & 3,0 & $5,6-5,7$ & $\begin{array}{c}\text { батон масою } \\
100 \text { г }\end{array}$ \\
\hline $\begin{array}{l}\text { Сир плавлений “Український” із спецією } \\
\text { "Українська кухня” }\end{array}$ & 40 & 51,7 & 2,8 & 5,6 & $\begin{array}{c}\text { батон масою } \\
100 \Gamma\end{array}$ \\
\hline
\end{tabular}

Традиційно, фізико-хімічні методи досліджень об’єднують групу методів, що грунтуються на залежності фізичних властивостей речовини від іï природи. Величина фізичної властивості, яка функціонально пов'язана 3 концентрацією або масою компонента, що визначається, становить аналітичний сигнал. Аналіз цифрового матеріалу показує максимально-наближені величини жиру в сухій речовині; вологи, солі і $\mathrm{pH}$ до характеристик прототипу базового продукту - плавленого сиру “Гострий із перцем".

Як видно, з аналогічної таблиці дослідні зразки сиру фасувались у традиційні форми (батончики), так і у форми кружків. Маса дослідних зразків сиру була в межах 100 г. Масова частка жиру у сухій речовині складає так само як і у базовому продукті (нормативні вимоги - 40 \%). Всі дослідні зразки сиру характеризувались однаковими величинами масової частки вологи - 51,7\% проти $52 \%$ у прототипі, вміст солі 2,8\% проти 3,0 \%, а рН дослідних зразків плавленого сиру “Український” відповідно складав 5, 6, що відповідає нормативним вимогам.

Як відомо, важливою складовою на завершальному етапі оцінки готової продукції $є$ іiі дегустаційна оцінка. Дегустаційна оцінка має на меті оцінку товарних, смакових і товарознавчих характеристик. 3 метою більш чіткої оцінки якості продукції під час проведення дегустації застосовується більша оцінка. При бальній оцінці плавлені сири оцінюють за шкалою 3 30 балів. При цьому, якщо виявляються невеликі вади, роблять певні скидки, оцінюючи їх також у балах.

Як видно із результатів дегустаційної оцінки зразків, всі вони відповідали нормативним вимогам i отримали досить високі характеристики (відповідно 28 та 29 балів).

Показники безпеки плавленого сиру із спечією “Украӥнська кухня”. Безпечність харчових продуктів - $\epsilon$ технологічною характеристикою, яка описує обробку, підготовку та зберігання харчових продуктів, недопущення проявів хвороб харчового походження. Важливими характеристиками всіх харчових продуктів $\epsilon$ їх безпека. При виробництві плавлених сирів із спеціями показниками їх безпеки є вміст важких металів та мікробіологічні показники.

Як відомо, плавлені сири належать до перероблених сирів. Плавлені сири мають деякі переваги у порівнянні з натуральними сирами, а саме: під час плавлення гине значна частина мікроорганізмів, що позитивно впливає на стійкість продукції під час зберігання, а відсутність кірки полегшує догляд за ними під час зберігання.
В той же час, дотримання всіх правил санітарнотехнологічної обробки дозволяє отримувати та гарантувати технологічну безпеку пропонованої продукції. При виробництві плавлених сирів основними показниками безпеки $є$ дослідження ї на вміст важких металів та спеціальні мікробіологічні дослідження. Проведені дослідження по вмісту важких металів у дослідних зразках плавленого сиру із пропонованою фітоспецією засвідчили, що рівень вмісту важких металів по кожному 3 них не перевищував допустимих норм, а ртуті і миш'яку не виявлено взагалі.

Паралельно була проведена мікробіологічна оцінка плавлених сирів При оцінці отриманих даних як традиційна продукція, так і дослідні зразки мали нормативні показники безпеки. В той же час шкідливої та небезпечної мікрофлори виявлено не було.

Підсумовуючи вище наведені експериментальні дані, можна відзначити, що використання в якості рецептурного складника для виробництва плавленого сиру спеції "Українська кухня" на основі плавленого сиру "Гострий із перцем" є доцільним, а отримана продукція є біологічно цінною, має належні товарознавчі характеристики, показники безпеки і розширює асортимент вітчизняної молочної продукції лікувально-профілактичного спрямування. Дослідження захищені патентом.

\section{Висновки}

1. Доведено можливість використання фітоспеції "Українська кухня" в технології плавленого сиру. Застосована фітоспеція "Українська кухня" є стандартною вітчизняною новою фітоспецією, що не потребує суттєвого ускладнення технологічного процесу виготовлення плавленого сиру лікувальнопрофілактичного спрямування.

3. Розроблено виробничу рецептуру плавленого сиру із фітоспецією "Українська кухня".

4. Вивчено органолептичні, технологічні властивості та показники безпеки дослідних зразків плавленого сиру із фітоспецією "Українська кухня".

\section{References}

Boichak, Ya., Koberniuk, V., \& Petryk, L. (2018). Novi vydy i formy biodobavok $\mathrm{v}$ tekhnolohii molochnykh produktiv LPN. Dni studentskoi nauky u LNUVM ta BT imeni S. Z Hzhytskoho: Materialy studentskoi konferentsii. Lviv, 79-80 (in Ukrainian).

Gachak, Yu. R., Gutyj, B. V., Benitska, A., Dyakun, T., Pristantsky, R., \& Kinitska, L. (2017). Use of «Ama- 
rant» cryoproush in the technology of dairy products of treatment and propofilactic degradation. Scientific Messenger LNUVMB, 19(80), 57-62. doi: $10.15421 /$ nvlvet8012

Gutyj, B., Hachak, Y., Vavrysevych, J., \& Nagovska, V. (2017). The elaboration of cheese masses of therapeutic and prophylactic direction with cryoadditive «Pumpkin». EUREKA: Life Sciences, 1, 19-26. doi: 10.21303/2504-5695.2017.00306.

Gutyj, B., Hachak, Y., Vavrysevych, J., \& Nagovska, V. (2017). The influence of cryopowder "Garbuz" on the technology of curds of different fat content. EasternEuropean Journal of Enterprise Technologies. 2, 10(86), 20-24. doi: 10.15587/1729-4061.2017.98194.

Hachak, Yu. R. (2011). Sposib vyrobnytstva syru "Domashnii”" iz spetsiiamy i prianoshchamy. PU № 3687. Kyiv (in Ukrainian).

Hachak, Yu. R., \& Mykhailytska, O. R. (2014). Zastosuvannia roslynnoi biodobavky $\mathrm{v}$ tekhnolohii plavlenykh syriv. Zbirnyk materialiv naukovoi konferentsii "Ozdorovchi kharchovi produkty ta diietychni dobavky: tekhnolohii, yakist ta bezpeka". Kyiv: NUKhT, 31-32 (in Ukrainian).

Hachak, Yu. R., \& Sadykova, V. I. (2011). Sposib vyrobnytstva syru «Domashnii» iz spetsiiamy i prianoshchamy. Patent na korysnu model № 3687 , Kyiv (in Ukrainian).

Hachak, Yu., Gutyj, B., Bilik, O., Nagovska, V., \& Mykhaylytska, O. (2018). Effect of the cryopowder "Amaranth" on the technology of molten cheese. Eastern-European Journal of Enterprise Technologies, 1(11(91)), 10-15. doi: 10.15587/17294061.2018.120879.

Hoiko, I., \& Pryshepa, M. (2014). Zastosuvannia kropu, cheremshi, bazyliku u vyrobnytstvi kyslomolochnoho syru. Zbirnyk mizhnarodnoi naukovo-praktychnoi konferentsii "Ozdorovchi kharchovi produkty ta diietychni dobavky, tekh-nolohii, yakist ta bezpeka" Kyiv: NUKhT, 15-16 (in Ukrainian).

Hrek, O. V., \& Skorchenko, T. A. (2012). Tekhnolohiia kombinovanykh produktiv na molochnii osnovi: Pidruchnyk. K.: NUKhT (in Ukrainian).
Ilinska, A., Benytska, A., \& Prystanskyi, R. (2017). Krioporoshky $\mathrm{v}$ yakosti biodobavok u molochnykh produktakh LPN. Aktualni zadachi suchasnykh tekhnolohii6 zbirnyk tez dopovidei n. t. konferentsii molodykh uchenykh ta studentiv. Ternopil, $174-175$ (in Ukrainian).

Koberniuk, V., Ilinska, A., \& Hrabarchuk, O. (2018). Novi vydy krioporoshkiv $\mathrm{v}$ tekhnolohii molochnykh produktiv LPN. Dni studentskoi nauky u LNUVM ta BT imeni S. Z Hzhytskoho: Materialy studentskoi konferentsii. Lviv, 103-104 (in Ukrainian).

Kozak, M. V., Hachak, Yu. R., \& Ostapiuk, Yu. I. (2012). Veterynarno-sanitarnyi ta tekhnolohichnyi kontrol moloka, molochnykh produktiv. Lviv (in Ukrainian).

Lanycja, I. (2017). Estimation of quality of foods of processing to the amaranth. Scientific Messenger of LNU of Veterinary Medicine and Biotechnologies, 19(75), 8184. doi: 10.15421/nvlvet7516.

Pavliuk, R. Yu., Poharska, V. V., Khomenko, A. V., \& Kostrova, K. V. (2013). Biotechnology of fermented milk drinks using buttermilk and additives of spicy vegetables. Eastern-European Journal of Enterprise Technologies, 4(10(64)), 53-57. Available at: http://journals.uran.ua/eejet/article/view/16315/138 38.

Shidlovskaja, V. P. (2000). Organolepticheskie svojstva moloka i molochnyh produktov. Spravochnik. M.: Kolos (in Russian).

Steshenko, M., Arsenyeva, L., Royko, A., \& Palamarchuk, A. (2015). Plant research phenolic compounds adaptogen with a view to the recipe functional food. Scientific Messenger of LNU of Veterinary Medicine and Biotechnologies, 17(4), 130135. Retrieved from: https://nvlvet.com.ua/index.php/ journal/article/view/616.

Yatsenko, I. V., Bohatko, N. M., Bukalova, N. V., Fotina, T. I., Biben, I. A., Berhilevych, O. M., Hachak, Yu.R., Tkachuk, S. A., Kamianskyi, V. V., Bondarevskyi, M. M., Zazharska, N. M., Tsyvirko, I. L., \& Kasianenko, O. M. (2016). Hihiiena moloka i molochnykh produktiv. Chastyna 2. Hihiiena molochnykh produktiv: Pidruchnyk. Kharkiv: "Disa plius" (in Ukrainian). 